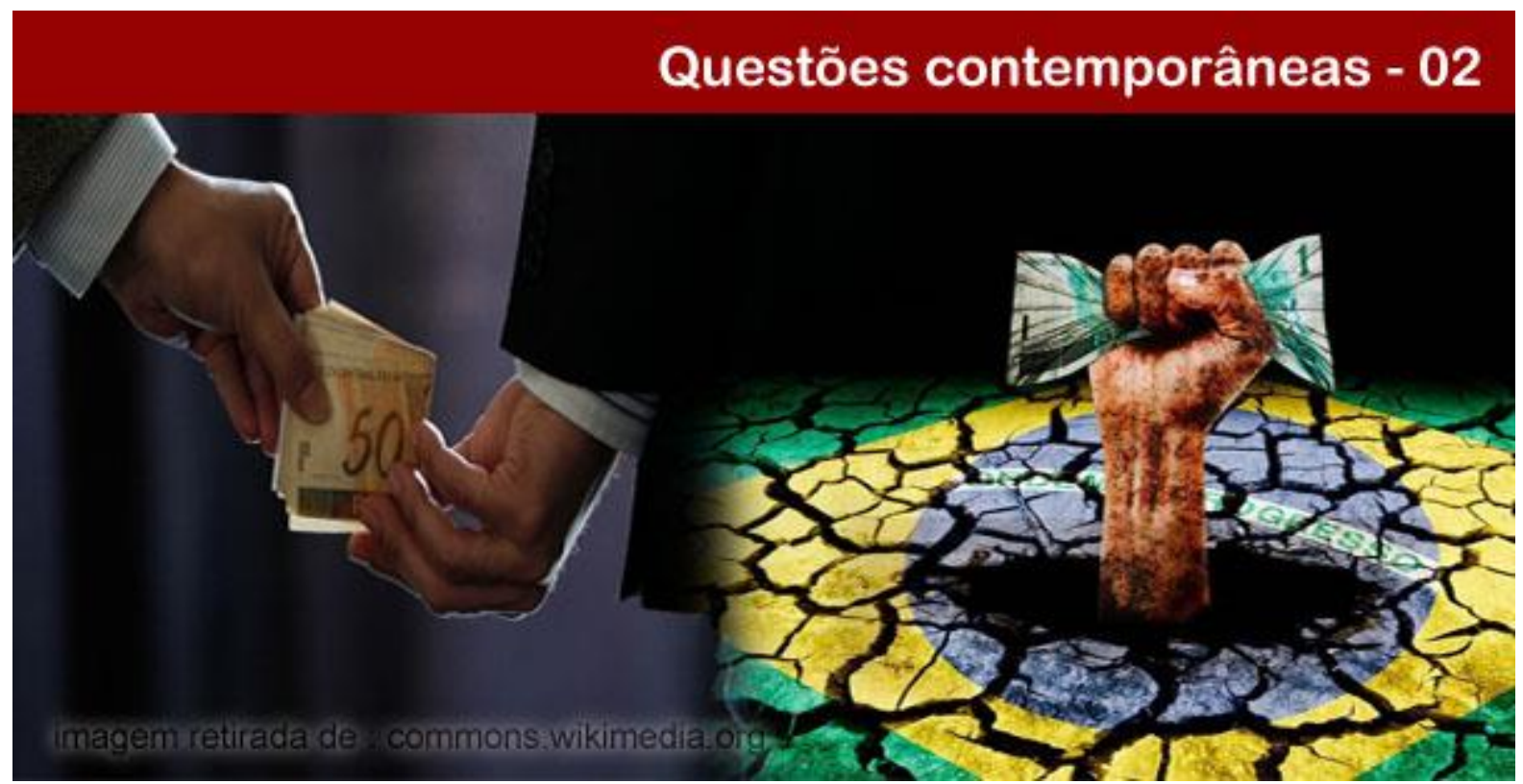

\title{
PENSAMENTO SOCIAL DOS BRASILEIROS SOBRE CORRUPÇÃO OS BRASILEIROS E A CORRUPÇÃO
}

Ricardo Vieiralves de Castro

Pós-doutorando em História Social pela Universidade de São Paulo (USP). Doutorado em Comunicação pela Universidade Federal do Rio de Janeiro (UFRJ). Mestrado em Psicologia Clínica pela Pontifícia Universidade Católica do Rio de Janeiro (PUC/RJ). Graduação em Psicologia (licenciatura e bacharelado) pela Universidade do Estado do Rio de Janeiro (UERJ). Professor Associado da Universidade do Estado do Rio de Janeiro.

Resumo: O artigo é um ensaio teórico sobre o pensamento social dos brasileiros sobre si mesmos, sob o tema da corrupção. Articula as teorias psicossociais contemporâneas do pensamento social, em especial as de memória e representações sociais, com o modo de pensar e agir dos brasileiros em relação a corrupção. A partir do conceito de marcos referenciais promove interfaces da psicologia social com a história e estabelece, com base em alguns fatos, as condições de permanência e atualização de formas de pensamento social entre os brasileiros. A corrupção para os brasileiros é considerada como um ato de negociação provocado pela indefinição de identidades, compreendida como formas de pensamento social, e pelo estabelecimento de um modo de pensar e agir em bordas moles, compreendidas como limites identitários maleáveis que estabelecem um modo de relacionamento social sem definição de regras claras e de valências.

Palavras-chave: Pensamento social. Brasileiros. Corrupção.

\section{BRAZILIANS' SOCIAL THINKING ON CORRUPTION THE BRASILIANS AND THE CORRUPTION}

Abstract: The article is a theoretical essay on the social thinking of Brazilians on themselves, under the theme of corruption. Articulates the contemporary psychosocial theories of social thought, especially memory and social representations, with the way of thinking and acting of Brazilians about corruption. From the concept of benchmarks promotes social psychology interfaces with the history and sets, based on some facts, the conditions of stay and updating forms of social thought among Brazilians. Corruption for Brazilians is considered an act of trading caused by identity vagueness, understood as forms of social thought, and the establishment of a way of thinking and acting in soft edges, understood as malleable identity boundaries that establish a social relationship without defining clear rules and valences.

Keywords: Social thinking. Brazilians. Corruption.

\section{POLÊM!CA $\mid$ LABORE (}

Polêmica - Revista Eletrônica da Uerj - Rua São Francisco Xavier, 524, $1^{\circ}$ andar bloco D, sl.1001 • Tels.: +55 21 2334-4088/4087 • http://www.e-publicacoes.uerj.br/index.php/polemica/index http://www.labore.uerj.br • laboreuerj@yahoo.com.br 
Em uma piada sobre corrupção no Brasil, Novaes (1978), tendo como referência uma campanha publicitária do governo autoritário de então, assim a representa: "Pergunta feita ao telefone por um cidadão bem estabelecido a uma autoridade, logo após saber que o Brasil é feito por nós: - Escuta. Eu também 'tô' aí nessa boca?” (p. 59).

Há, na escolha desta piada, elementos que devem ser destacados para a melhor compreensão do que os brasileiros pensam socialmente sobre a corrupção, o que a torna relevante para as abordagens de diferentes aspectos do cotidiano no Brasil. As piadas, em geral, são datadas no tempo e na circunstância cultural em que foram produzidas (POSSENTI, 2014). Essa, entretanto, atravessa tanto a circunstância, uma campanha publicitária da ditadura militar, quanto o tempo, pela compreensão que ainda produz. A transcendência deste texto está diretamente associada à representação dos brasileiros sobre si mesmos de que a corrupção é parte integrante do caráter do povo brasileiro e que é constituinte de sua identidade (AVRITZER, BIGNOTTO, GUIMARÃES, STARLING, 2008):

Há um senso comum recorrente que associa o fenômeno da corrupção à própria identidade do brasileiro. Por essa visão, o Brasil seria inevitável e definitivamente corrupto devido a certos valores e práticas que, presentes desde a origem, tornaramse parte de seu caráter e de seu jeito de ser. (p. 14).

Os personagens da piada: uma autoridade pública e um "cidadão bem estabelecido", explicitam os agentes da corrupção brasileira. Há, também, uma redução no senso comum da corrupção aos agentes públicos de Estado, autoridades e funcionários públicos, e a seus parceiros abastados que, "bem estabelecidos", dividem o butim.

Avritzer et al. (2008) reconhecem esta situação nas representações dos brasileiros e acrescem o fato de que também entre acadêmicos e intelectuais há esta redução:

Um procedimento recorrente nos estudos da corrupção é a concentração da atenção no comportamento dos funcionários do Estado que se desviam de suas funções. Essa abordagem do problema tem suas raízes na maneira como a lei brasileira caracteriza a prática da corrupção, mas conserva também as marcas de uma abordagem teórica, que privilegia o estudo daqueles que estão diretamente ligados à máquina do Estado. (p. 13).

Também há que se considerar que o tema é recorrente na avaliação do Estado brasileiro e de seus governos. Na recente história republicana brasileira, as crises políticas sempre foram acompanhadas de denúncias sobre a corrupção de governos. Assim foi na crise

\section{POLÊM!CA $\mid$ LABORE}


de agosto de 54 com Getúlio Vargas, com o discurso sobre a necessidade de instauração da ditadura militar (1964-1984) e, atualmente, é o "alimentador" da crise. Em momentos de crise política e econômica, a corrupção do Estado é estabelecida em protagonismo.

Há, entretanto, uma contradição lógica nestas representações sobre a corrupção do Brasil e dos brasileiros, onde, em princípio, uma anula a outra. Se a corrupção é parte do caráter dos brasileiros (em uma definição de povo) ela não pode ser restrita aos agentes públicos de Estado. No mesmo entendimento lógico, o oposto também não se aplicaria.

O que é singular, porém, é que estas formas distintas e dicotômicas de pensar convivem no cotidiano dos brasileiros e estruturam modos e práticas em relação à corrupção, não se anulando mutuamente. Os dois discursos convivem no mesmo espaço social do cotidiano, assim sendo, os brasileiros são corruptos e a corrupção, ao mesmo tempo, é restrita.

Estas formas de pensar têm efeitos em práticas sociais e estruturam modos de relações no cotidiano entre os brasileiros e nas relações com o Estado. Entretanto, se a corrupção é um acontecimento "generalizado e universal", em sua dimensão histórica e temporal, como geográfica e territorial, no Brasil, e entre os brasileiros, ganha singularidade e expressões próprias que distinguem esta prática das de outros lugares do planeta.

Escolhemos alguns acontecimentos históricos brasileiros para a discussão deste tema. As razões de tal escolha devem-se a três condições: a apropriação singular do fato histórico pelos brasileiros que o ressignificam; sua transcendência e atualização, o que relaciona com conceitos de teorias do pensamento social, e porque estes acontecimentos contêm modos de pensamento que definem o que pensam os brasileiros sobre si mesmos.

\section{No decorrer da história}

A $2^{\circ}$ Guerra provocou uma significativa transformação nas teorias psicológicas sobre o social. Os acontecimentos derivados da ascensão do nazifacismo expuseram fenômenos, que mesmo ocorrendo antes deste evento, ganharam dimensões massivas e para além de nacionalidades e de indivíduos. Tal intensidade obrigou diversos intelectuais, de diferentes abordagens epistemológicas, a produzir possíveis interpretações destes fenômenos do comportamento humano. Nestas análises, há prevalência do social e as interações entre indivíduos destacaram-se sobre uma determinada compreensão psicológica restrita ao sujeito. As teorias psicológicas originadas com forte influência da metafísica sob referência da

\section{POLÊM!CA $\mid$ LABORE}


descrição e definição ontológica foram, por este acontecimento histórico de grande intensidade, deslocadas para outros paradigmas teóricos e metodológicos.

Farr (2013) afirma que:

\begin{abstract}
Os paradigmas são importantes para a coerência de uma disciplina, mas eles próprios podem ser perturbados por acontecimentos externos ao paradigma. Há poucos acontecimentos mais perturbadores para ciência normal do que a guerra. [...] a era moderna, na psicologia social, começou com o fim da segunda guerra mundial. (p. 184)
\end{abstract}

Mesmo teorias que consideravam interpretações mais focadas no sujeito e no indivíduo, como a psicanálise, foram provocadas a se debruçarem sobre estes fenômenos sociais, por sua abrangência, intensidade e consequência.

Os autores em psicologia social consideraram este conceito/objeto, pensamento social, como um novo paradigma que exigia a construção de teorias suficientes para permitir um entendimento fora do domínio exclusivo do subjetivo ou das experiências laboratoriais. Um campo epistemológico novo se estruturava sobre as possibilidades de compreender o acontecimento social e, especialmente, a partir da dinâmica inter-relacional.

Moscovici (2012) é um dos autores importantes deste período. Em seu trabalho teórico, elevou de maneira original o senso comum, até então, desprezado no âmbito das ciências humanas e sociais, como um objeto central para a psicologia social e um caminho privilegiado para a aproximação e compreensão da dinâmica e do processo de formação do pensamento social. O senso comum, considerado como uma caricatura vulgar e distorcida do pensamento erudito e científico, torna-se central para permitir o entendimento de um pensamento socialmente construído que define práticas sociais e modos de vida cotidianos.

O pensamento social se constituiu em duplicidade epistêmica: de conceito, que não mais acontecia no indivíduo stricto; e objeto capaz de ser identificado na investigação empírica. Esta nova abordagem inevitavelmente provocaria uma ruptura com a psicologia social estruturada em microteorias e, ao mesmo tempo, um desenvolvimento teórico complexo na aproximação com o acontecimento social.

Ser simultaneamente conceito e objeto não é simples. Há uma tensão epistêmica interna na delimitação dos limites entre um e outro, dificultando uma definição precisa quando é objeto e quando, ou em que situação, é conceito, o que ameaça de maneira constante a própria permanência deste conceito/objeto.

\title{
POLÊM!CA $\mid$ LABORE
}


A chave paradigmática das representações sociais é o compartilhamento. A constituição de uma representação social sobre um determinado objeto só pode acontecer a partir do compartilhamento entre diversos indivíduos que têm alguma espécie de "território comum", mesmo que este território seja o acesso aos mesmos meios de comunicação (o que fez Moscovici [2012] no estudo inicial sobre a representação social da psicanálise, quando analisou a imprensa francesa). Ou seja, uma noção de "território" fluida e com muitas possibilidades de determinação de limites ${ }^{1}$.

Há, no mundo contemporâneo, uma descentralização do conceito de identidade. A mobilidade social e o pertencimento de indivíduos a diversos grupos de interesses e de atividades dificultam o estabelecimento de limites identitários, que seriam fundamentais para a explicitação de lugares comuns circunscritos que definem quem são os que pensam socialmente e que lócus compartilham.

A dificuldade no mundo contemporâneo na delimitação de identidades, associada à fluidez destes territórios, move a definição dos sujeitos que compartilham uma representação social para as definições clássicas das ciências sociais: de classe, de ocupação profissional, de posicionamento rural e/ou urbano etc.; ou as movem para um campo múltiplo de definições que podem produzir resultados excessivamente circunstanciais e atomizados.

Esta fluidez também se manifesta nos instrumentos metodológicos que produzem uma redução nos "surveys" sociológicos e uma certa simplificação nas análises qualitativas, diante da dificuldade de tratar as contradições lógicas e estruturais do senso comum. Neste aspecto, a aproximação com as ciências humanas e sociais faz com que haja, necessariamente, uma apropriação de um conceito (de "fora" da psicologia social) para ser transformado em outro adequado ao campo epistemológico da psicologia social. No estado atual da psicologia social não se considera possível a constituição teórica sem esse diálogo e sem esta interlocução, o que significa, em outros termos, que a psicologia social deve compulsoriamente conhecer, apropriar e transformar conceitos de outras ciências humanas e sociais.

Moscovici (2012) e Jodelet (2001) afirmaram que uma representação social é constituída através de um processo de compartilhamento e que esse "conhecimento do senso comum" persiste e estrutura modos de vida e práticas no cotidiano.

\footnotetext{
${ }^{1}$ As ciências sociais stricto sensu identificam territórios mais delimitados. O conceito de classe social, ou "sítios antropológicos" da etnografia clássica são "territórios" que limitam e constituem identidade grupal.

\section{POLÊM!CA $\mid$ LABORE}


O diálogo com as ciências sociais permite à psicologia social a criação de modelos hermenêuticos, que se estabelecem como chaves de interpretação para acontecimentos psicossociais e permitem as devidas aproximações para a melhor circunscrição do pensamento social. A relação da psicologia social com a história é fundamental para que as teorias existentes sobre o pensamento social, em especial memória e representações sociais, atribuam sentidos aos saberes e lembranças que persistem e se atualizam.

Neitzel e Welzer (2014), na análise das gravações de pronunciamentos e conversas de soldados nazistas alemães, estabeleceram, como possibilidade de interpretação de comportamentos e discursos, o que denominaram de marcos referenciais. Para estes autores, os marcos referenciais são matrizes ordenadas de modelos interpretativos aproximando a psicologia social da história.

Modelos hermenêuticos são como chaves de interpretação para acontecimentos psicossociais e permitem aproximações para a melhor circunscrição do pensamento social. $\mathrm{O}$ modelo hermenêutico que estes autores utilizaram foi classificado em quatro ordens. Os marcos referenciais de primeira ordem "abrangem a estrutura histórico-social de fundo diante da qual as pessoas, no tempo respectivo, atuam" (NEITZEL, WELZER, 2014, p. 23). Eles estabelecem escalas de valores, de hábitos, de juízos e de códigos de convivência. Estes marcos referenciais de primeira ordem não são objeto, em geral, de reflexão, mas de planos emocionais e que instituem práticas que são exercidas por todos, sem a consciência de sua origem e de sua causa, em um processo de inconsciência reflexiva.

Os marcos referenciais de segunda ordem têm uma dimensão mais concreta histórica e geograficamente. "Eles abrangem um espaço histórico-social que pode ser delimitado das mais diversas perspectivas - pela duração de um regime de dominação, por exemplo, pelo período de vigência de uma constituição ou pela época de uma formação histórica, como o Terceiro Reich.” (NEITZEL, WELZER, 2014, p. 24). Estes marcos referenciais de segunda ordem, para serem identificados, precisam da história.

Os marcos referenciais de terceira ordem são, segundo os autores, ainda mais específicos. "Eles tratam de uma cadeia concreta de acontecimentos histórico-sociais, na qual pessoas determinadas atuam, como uma guerra, em que elas combatem como soldados" (NEITZEL, WELZER, 2014, p. 24). Estes acontecimentos precisam de relevância estabelecida pelo grau de envolvimento de pessoas, de alterações da ordem estabelecida, de

\section{POLÊM!CA $\mid$ LABORE}


efeitos diversos do cotidiano. Não há como referenciá-los sem o diálogo com a ciência política.

E, por fim, os marcos referenciais de quarta ordem, onde cada "uma das características especiais, modos de percepção, modelos interpretativos, deveres de consciência etc. que toda a pessoa traz para uma situação. Nesse nível, trata-se de psicologia, de disposições pessoais e da questão do processo individual de tomada de decisão" (NEITZEL, WELZER, 2014, p. 24). Estes marcos referenciais de quarta ordem podem ser revistos na ênfase individual proposta por aqueles autores.

As chaves hermenêuticas destes marcos referenciais de quarta ordem foram estabelecidas nos diversos saberes constituídos a partir daqueles marcos anteriores, entretanto, por vezes, e isto é curioso, as chaves hermenêuticas que se apoiam em eventos anteriores se estabelecem para além de tempos históricos delimitados e definidos. Estes marcos referenciais não são como arquétipos ou sistemas inframentais de referências interpretativas, eles acontecem na dinâmica da vida social, na inter-relação entre os indivíduos e são retroalimentados e mantidos nas práticas do cotidiano.

Moscovici (2003) vai ao encontro desta perspectiva hermenêutica do pensamento social quando, debatendo sobre o status epistemológico da teoria das representações sociais, afirma que:

É uma teoria geral à medida que, dentro do que lhe compete, uma sociedade não poderia ser definida pela simples presença de um coletivo, que reuniu indivíduos através de uma hierarquia de poder, por exemplo, ou através de intercâmbios baseados em interesses mútuos. Certamente existem poder e interesses, mas para serem reconhecidos como tais na sociedade devem existir representações ou valores que lhe deem sentido [...] (MOSCOVICI, 2003, p. 173).

O pensamento social é dinâmico e isto transcende uma compreensão ontológica de que este dinamismo ocorre nas adaptações das mudanças sociais e do tempo, mas que também, como exercício e construção hermenêutica, "desmonta" uma rigidez linear de tempo, fazendo com que o passado, ou construções de saberes do passado, sejam reatualizados e permaneçam.

Aproximar-se do esforço de compreensão dos brasileiros, seus modos de pensar e agir, tende a ser uma espécie de Oráculo de Delfos ao revés. Ao invés de encontrarmos a solução do enigma da esfinge e decifrar nossos modos de pensar e agir, podemos aumentar, por sua complexidade e redes de conexão teóricas e empíricas, o próprio enigma.

\section{POLÊM!CA $\mid$ LABORE}


Para considerar que os brasileiros constituíram um modo de pensar socialmente muito distinto é preciso estabelecer relações com o processo histórico de formação do Brasil. A "dificuldade" de estabelecer uma compreensão de si mesmos bem delimitada e claramente constituída fez com que os brasileiros se autorrepresentassem, lembrassem ou esquecessem fatos e acontecimentos de maneira muito distinta, e isso se deve a uma série de razões extremamente complexas.

Para efeito de demonstração destas representações, destacamos alguns, entre muitos marcos, como referências para o desenho contemporâneo do pensamento social dos brasileiros em relação à corrupção. Esses marcos foram escolhidos por transcender o tempo em que estavam inscritos e se manterem atualizados nas estruturações do pensamento social dos brasileiros sobre si mesmos.

A primeira escolha é Gregório de Matos. Em seu poema satírico sobre o governador Antônio de Souza Meneses, o Braço de Prata, assim disserta: "Plantar de fora o ladrão, quando a ladroice fica, será limpeza de mãos, mas de mãos mui pouco limpas" (MATOS, 1990, p. 145). Em outro trecho, sobre a Bahia:

Que falta nesta cidade? ...Verdade. Que mais por sua desonra .... Honra. Falta mais que se lhe ponha... Vergonha. [...]. Quem faz os círios mesquinhos?... Meirinhos. Quem faz as farinhas tardas?...Guardas. Quem as tem nos aposentos? ... Sargentos. [...] E que justiça a resguarda? .... Bastarda. É grátis distribuída?... Vendida. Quem tem, que a todos assusta?... Injusta. [...]. Que vai pela clerezia? ...Simonia. E pelos membros da Igreja... Inveja. Cuidei, que mais se lhe punha... Unha. [...]. A Câmara não acode?... Não pode. Pois não tem o poder?... Não quer. É que o governo a convence?... Não vence. (MATOS, 1990, p. 56-58).

As representações da corrupção generalizada nos aparelhos de estado, nos costumes e nas instituições, são apresentadas por Gregório, na Bahia do séc. XVII. Os poemas satíricos do Boca do Inferno tiveram por consequência degredo e prisões. É importante ressalvar que se há essa compreensão de que a corrupção se dissemina em todos os que viviam no Brasil de então, também há uma concepção cética de sua inevitabilidade e impossibilidade de superação, por estar, já como prática generalizada, estruturada em modos de vida. Gregório também não se poupa e considera-se incluso nesta forma de agir. A corrupção como prática generalizada e sem possibilidade de solução foi sendo atualizada, no decorrer da história, no pensamento social dos brasileiros.

\section{POLÊM!CA $\mid$ LABORE}


A história e o mito da relação do desembargador João Fernandes, contratador de diamantes no séc. XVIII, com Chica da Silva, é o outro marco referencial escolhido, pela complexidade e singularidade dos acontecimentos referentes. A relação de Chica da Silva, exescrava, com o contratador João Fernandes foi mitificada no cinema e na literatura, com representações de uma mulher plena de luxúria e de autoridade, envolvida com seu amante em contrabando de diamantes. Quando as autoridades descobrem a ilegalidade, o relacionamento é rompido e João Fernandes retorna a Portugal. Os estudos de Furtado (2003), baseados em fontes documentais, vão de encontro ao mito estabelecido e conferem novas facetas à esta história.

Furtado destaca singularidades na história de Chica da Silva, que é alforriada por João Fernandes logo após tê-la adquirido, acontecimento inusitado nos estudos comparativos com outras pretas alforriadas. Nos 17 anos de relacionamento com o contratador, Chica da Silva pariu 13 vezes e com um resguardo obrigatório de 3 meses, pode-se desprender que a face da luxúria foi criada pelo mito.

\footnotetext{
Durante dezessete anos, entre 1753 até 1770, ano em que João Fernandes voltou para Portugal, ele e Chica mantiveram um relacionamento estável, do qual nasceram treze filhos, nove meninas e quatro meninos. A média de um parto a cada treze meses faz desmoronar o mito da figura sensual e lasciva, devoradoras de homens, ao qual Chica esteve sempre ligada. João Fernandes jamais teve dúvidas sobre a paternidade dos rebentos, pois os legitimou e lhes legou todo o seu patrimônio, apesar de em seu testamento demonstrar a esperança de que ainda pudesse vir a ter um filho legítimo. (FURTADO, 2003, p. 121).
}

Duas outras representações constituídas pela literatura, cinema e apropriadas no senso comum, a de que Chica da Silva teve uma relação diferenciada com os escravos e a de que o retorno de João Fernandes para Portugal deveu-se a descoberta da ilicitude no contrabando de diamantes, também se demonstram falsas, segundo o estudo desenvolvido por Furtado. Na comparação com inventários de proprietários do Arraial do Tejuco, Chica da Silva situa-se entre os 6,1\% dos proprietários que possuíam mais de 20 escravos, mantendo o mesmo padrão de alforria dos senhores brancos.

Não há, na documentação avaliada, fatos que comprovem que houve ilegalidade no trato com os diamantes e que este tivesse sido o motivo da separação entre contratador e Chica da Silva, levando ao retorno de João Fernandes a Portugal. Ao que parece, foram

\section{POLÊM!CA $\mid$ LABORE}

Polêmica - Revista Eletrônica da Uerj - Rua São Francisco Xavier, 524, $1^{\circ}$ andar

bloco D, sl.1001 • Tels.: +55 21 2334-4088/4087 • http://www.e-publicacoes.uerj.br/index.php/polemica/index

http://www.labore.uerj.br • laboreuerj@yahoo.com.br 
questões de João Fernandes com seu pai e a madrasta sobre o uso do dinheiro obtido com o contrato de diamantes.

Várias representações interessam nesta história mitificada de Chica da Silva e João Fernandes que dizem respeito ao tema da corrupção. A mudança pela sedução sexual da condição de escrava, objeto e propriedade, em concubina, livre e com aceitação social restrita, não é pequena e nem insignificante. A ideia de um personagem que despertava luxúria e que possuía uma extraordinária competência sexual, atribuída a Chica da Silva, se contradiz pela estabilidade da relação e pela maternidade contínua. Se o concubinato foi um caminho possível para a conquista da alforria por escravas, isto não se manteve no pós-abolição e nas décadas seguintes da República, onde o concubinato foi definido de forma mais precisa em sua condição de ilegalidade, diminuindo e evitando que as mulheres negras tivessem o reconhecimento de uniões estáveis. O que se atualiza, entretanto, são representações de que as mulheres negras têm um poder de sedução inerentes à sua cor e, mesmo que escolhidas por homens brancos, os são para o encontro eventual ${ }^{2}$. O poder de sedução como corrupção da fidelidade conjugal atribuído às mulheres negras é constituído em um traço de natureza ontológica determinado pela cor.

As teorias raciais, especialmente eugenistas, propuseram-se a explicar condutas humanas como derivadas da condição de cor, especialmente a partir do final do século XIX. Silvio Romero (2001) considerava a mestiçagem brasileira inevitável e, apoiado em um tipo de interpretação da teoria da evolução, afirmava que o mestiço era um mal necessário porque, ao existir, melhorava, pela introdução da cor branca, a "raça" negra. Nina Rodrigues (2004), em seus textos do início do século, esperava comprovar a inferioridade dos negros e negras apoiada nas teorias eugenistas emergentes e, de maneira distinta de Romero (2001), afirmava que o mestiço seria o encontro desastroso do pior das "duas raças".

Quando se considera que a ação de corrupção, em qualquer nível e em larga escala, é inerente ao ser, neste caso por uma característica fenotípica - a cor, está implícita a representação entre brasileiros de que há herança genética para a predisposição à corrupção. A quantidade de chistes depreciativos que os brasileiros fazem de si mesmos é um signo desta forma de pensamento.

\footnotetext{
${ }^{2}$ Duas teses de doutorado recentes abordam esta questão: Vaz (2016) e Santos (2016).

\section{POLÊM!CA $\mid$ LABORE}


Na história relida, especialmente na película de Cacá Diegues (1976), a descoberta da relação entre o contrabando de diamantes e a excessiva riqueza do casal, com consequente punição, não findou o contrabando, mas substituiu o protagonismo. E uma das razões para a substituição dos atores foi a condição de poder excessivo que a negra Chica obteve no Tejuco. A associação entre fortuna e corrupção não é própria dos brasileiros, mas as razões para a sua revelação sim. Há, entre os brasileiros, representações de que se houve descoberta da corrupção não é para extingui-la ou evitá-la, mas para que outros venham a ocupar o lugar dos de antes, o que associa ao ceticismo de Gregório no século anterior. Os brasileiros não consideram que seja possível a existência de sociedade e estado sem corrupção. A desconfiança de atos de controle da corrupção é parte do modo de pensar dos brasileiros sobre si mesmos, principalmente, quando relacionada a qualquer espécie de mobilidade nas estruturas desiguais da sociedade brasileira.

Ainda se atribuiu à Chica da Silva um lugar ambivalente: de vítima (considerada irreal pelos documentos encontrados por Furtado (2003), pela representação de que sua rejeição foi por ter relações humanitárias com os escravos; e de algoz (também irreal nos documentos encontrados), por ter envolvido João Fernandes na sedução que o levou à ruína.

Este modo de representação se encontra articulado com o processo de formação histórica do Brasil em uma ambivalência que significa não atribuir valência/valor aos fatos e acontecimentos de alta relevância e intensidade ocorridos no Brasil. A ambivalência (in)define o acontecimento.

É interessante observar, de uma forma reduzida e simplificada, que os brasileiros apontam a "crueldade da escravidão" e exaltam o abolicionismo, mas também consideram a monarquia escravista boa, especialmente na figura do Imperador Pedro II; os índios eram preguiçosos e por isso não foram escravizados, mas também são exaltados por seu desejo de liberdade; a República foi uma solução política boa, mas também a Monarquia era boa e tinha vantagens. O Brasil deveria ser colonizado por outro povo, mas todos exaltam as vantagens culturais da "terrinha" como se ainda fossem descendentes de portugueses.

Estas afirmações de senso comum, simplificadas, trazem, no entanto, um propósito: "empatar" o dissenso e não estabelecer valência/valores sobre o fato. O "empate" mantém a indefinição de identidade e faz com que o fato e o acontecimento histórico sejam apreendidos

\section{POLÊM!CA $\mid$ LABORE}


em uma esfera de negociação. O esforço dos brasileiros, na negociação que fazem da história, é negociar o "empate".

Um outro personagem, que atravessa o período colonial até a abolição da escravatura, é também um marco referencial significativo para a aproximação das representações sobre corrupção: o capitão do mato. A escravidão negra que, segundo estimativas, desembarcou de maneira forçada entre 6 a 8 milhões de africanos no Brasil, de muitos povos e nações, pela subjugação aos senhores, diferenças entre seus povos, e estratégias políticas de domínio, também não constituiu, nem de maneira parcial, uma identidade negra brasileira que fosse capaz de (re)definir os brasileiros.

A estratégia de controle dos negros africanos que aqui aportavam e que depois ganhou um novo contorno com os seus descendentes que aqui nasceram, baseava-se em um tripé central: o primeiro era negar pela cor preta a condição de equanimidade humana, base de todas as ideias racistas; o segundo, agir com uma sofisticada relação entre "mercê" e "castigo", estabelecendo "prêmios e punições", nem sempre concedidas com regras claras, para que o escravo negro sempre demandasse e agisse por "mercê"; e o terceiro, dividindo os negros africanos aqui chegados, "misturando" povos rivais da África, impedindo a institucionalização de famílias negras, e atribuindo a negros as tarefas de punir ou "caçar" negros (os feitores e capitães do mato).

Lara (2007) aborda em seu texto que a "multidão de pretos" existentes no Brasil era uma ameaça constante de rebelião e que as elites não as subestimaram, criando estratégias sofisticadas de controle.

O oficial francês que esteve no Rio em 1748 e se surpreendeu com a grande concentração de negros, dizendo que a cidade parecia um 'verdadeiro formigueiro' não deixou de registrar que aquela 'concentração funesta' de escravos trazia consigo 'o constante perigo de uma rebelião'. [...] os cargos de capitão-do-mato foram regulamentados e o ofício generalizou-se por todo o Estado do Brasil. [...] Não por acaso, no mesmo período alguns jesuítas e letrados coloniais proferiam sermões e publicavam textos exaltando formas 'econômicas' e 'cristãs' de manter o controle sobre os escravos. Uma reflexão cuidadosa sobre as dimensões do 'governo econômico' dos senhores sobre seus cativos no interior das unidades produtivas também se desenvolveu, redimensionando o significado do castigo. Exemplar e mantendo um equilíbrio pedagógico entre rigor e mercê, ele também podia tornar-se instrumento preventivo de fugas e condição de continuidade do domínio senhorial. (LARA, 2007, p. 157-158).

Os negros "temidos" sofreram uma ação efetiva de desconstrução de qualquer possibilidade de identidade que fosse estendida ao país. O sentimento de negros brasileiros de

\section{POLÊM!CA $\mid$ LABORE}

Polêmica - Revista Eletrônica da Uerj - Rua São Francisco Xavier, 524, $1^{\circ}$ andar

bloco D, sl.1001 • Tels.: +55 21 2334-4088/4087 • http://www.e-publicacoes.uerj.br/index.php/polemica/index http://www.labore.uerj.br • laboreuerj@yahoo.com.br 
que houve ações efetivas de desmonte e desconstrução de qualquer espécie de amalgama identitário é percebido na pesquisa de Rios e Mattos (2005) sobre as lembranças de descendentes de escravos no estado do Rio de Janeiro, estabelecendo linhas de continuidade e descontinuidade entre o tempo do cativeiro e da liberdade. A situação social dos negros brasileiros mantinha, pela urgência da sobrevivência, a impossibilidade de constituição de qualquer espécie de unidade simbólica ou política.

A presença da "multidão de pretos" no Brasil imperial foi confirmada no censo de 1872 (NPHED, 2012) com a distribuição da população brasileira entre 37,9 \% de brancos, $38,2 \%$ de pardos, $19,7 \%$ de pretos e $3,9 \%$ de caboclos, perfazendo quase $2 / 3$ da população brasileira com cor.

O capitão do mato era, em geral, um escravo liberto ou alforriado que tinha como função principal a captura de negros fugidos em troca de uma remuneração denominada de tomadia paga pelo senhor do escravo (MOURA, 2004). Apoiado na inexistência de uma identidade negra no Brasil, o capitão do mato constituiu-se na escala escravo/não escravo e a sua ação de captura de negros escravos estava nesta esfera da alteridade.

Há relatos documentais de que capitães do mato sequestravam negros escravos para depois alcançar a remuneração, ou que estavam envolvidos no tráfico clandestino de escravos (SOARES, 2007).

O pertencimento é fundamental para o estabelecimento de pensamentos sociais sobre identidade, nas lembranças e esquecimentos e na valoração dos fatos. O capitão do mato, estando na condição de liberto, não pertencia mais ao mundo dos escravos e, por consequência, não se identificava com os assemelhados em cor que pertenciam àquele mundo ${ }^{3}$. No mundo dos livres, em sua maioria brancos, o capitão do mato era um serviçal que agia contra a mobilidade (de escravo para fugido ou quilombola) e tratado como um mal necessário, conceito que vigorará em várias teorias sociais com consequências na estruturação do código civil e penal (como no caso da prostituição/lenocínio). Este serviço "sujo" de manter bordas duras para a mobilidade, sua aceitação parcial no mundo dos livres, e a possibilidade de alterar contratos através de corrupção e ilegalidades, fizeram do capitão do mato um ofício que despertava sentimentos ambivalentes.

\footnotetext{
${ }^{3}$ É preciso ressalvar que quando se trata de identidade, não há correspondência com o conceito antropológico. Utiliza-se, aqui, identidade em uma perspectiva psicossocial associada ao pensamento social que se refere basicamente à representação que se faz de si mesmo e de quem se considera próximo ou igual.
}

\section{POLÊM!CA $\mid$ LABORE}


O capitão do mato traz, em consequência, uma associação entre ofícios e corrupção tolerada ou consentida: para aqueles que compensam com atos ilícitos a condição do "serviço sujo", ou para outros que compensam seus atos de promoção de benefícios para a população com enriquecimento, e neste caso, estariam situados os políticos que, ao estilo atribuído à Ademar de Barros, "rouba, mas faz". Uma espécie de tautologia ética que Mario de Andrade bem caracterizou em seu herói sem caráter.

Já no período republicano, o suicídio do Presidente Vargas é um marco referencial de grande intensidade social. Em agosto de 1954, o Presidente Vargas vivia uma grave crise institucional e política. Seus opositores, especialmente o deputado Carlos Lacerda da UDN (União Democrática Nacional), denunciava, com o apoio de vários setores da mídia de então, da elite nacional e de setores das forças armadas, em especial, a Aeronáutica, que o Brasil estava envolto em um "mar de lama", como uma metáfora da corrupção do governo.

Um atentado contra Lacerda, que provoca a morte do Major Vaz da Aeronáutica, revela o envolvimento de Gregório Fortunato, chefe da guarda pessoal do Presidente Vargas. Este fato aumenta a crise e a instabilidade política do Brasil, com o fortalecimento da oposição a Getúlio. Vargas tenta negociar politicamente saídas para a crise. Sua oposição exige sua deposição. Nas primeiras horas do dia 24 de agosto de 1954, o Presidente Vargas, em seu dormitório no Palácio do Catete, comete o suicídio com um tiro no peito.

Assim que Heron Domingues anuncia no Repórter Esso o suicídio de Vargas, há a destruição de prédios e equipamentos dos jornais de oposição; uma "romaria" ao Palácio do Catete para a visitação do corpo em câmara ardente; e uma multidão acompanhando o corpo até o Aeroporto Santos Dumont para o embarque até São Borja, onde Getúlio foi enterrado.

As estimativas censitárias (IBGE, 2016), para o meio dos 50, era de que $95 \%$ da população brasileira fosse católica romana. A igreja católica tem o suicídio como um pecado grave, inclusive não permitindo que os suicidas fossem enterrados em "campos santos", entretanto, o suicídio de Vargas provocou uma intensa mobilização afetiva que transformou o ato voluntário da morte em heroísmo.

Na tradição judaico/cristã, Sansão é um personagem que transforma o suicídio em ato heroico. Sua morte provoca a morte dos filisteus e liberta os judeus do jugo. A carta testamento de Getúlio o aproxima do mito de Sansão onde o ato voluntário da morte é associado a heroísmo no combate ao imperialismo americano e aos interesses contra os mais

\section{POLÊM!CA $\mid$ LABORE}


pobres. O heroísmo de Vargas obnubila o "mar de lama" e lhe associa ao povo mais pobre e aos interesses nacionais.

No entanto, há alguns detalhes e acontecimentos que tornam o suicídio de Getúlio em algo mais complexo. Castro (2005), em um artigo sobre Getúlio, afirma que uma imagem de N. Sra. Aparecida foi colocada no seu quarto, de ampla visitação no Museu da República e, desta maneira, Vargas agnóstico e suicida foi aproximado da igreja católica, na dimensão popular da religiosidade. $\mathrm{O}$ autor também destaca que vários visitantes do dormitório do presidente questionam os funcionários sobre a veracidade do suicídio, trazendo dúvidas sobre sua morte, estabelecendo possibilidades de um assassinato.

Um fato objetivo, o suicídio, é acrescido de versões que tem como efeito a dificuldade no estabelecimento de valências e na atribuição de juízos históricos, permitindo a criação de um lócus de negociação de sentidos e significados. As múltiplas atribuições a Vargas não só o tornam um personagem complexo, mas indefinido.

Estes acontecimentos destacados, entre muitos no Brasil, permitem uma aproximação com o pensamento social dos brasileiros sobre si mesmos: em primeiro lugar, em função da dimensão temporal das representações, que atualiza e permanece o passado; em segundo lugar, pelas múltiplas versões, inclusive antagônicas, e por fim pelo espaço de negociação que estabelece.

\section{E tudo se negocia}

Em Rocha (2003), encontramos um debate sobre o Brasil e os brasileiros, recorrentes em vários intelectuais, que define paradoxalmente o Brasil no futuro, o que o faz indefinido no presente, e com insuficientes acontecimentos, pensamentos e representações no passado que o fazem "existir". Rocha justifica a sua escolha por este paradoxo afirmando que:

[...] no caso da 'teologia negativa' da tradição brasileira, o fenômeno se inverte, pois, dada a incompletude constitutiva do objeto - o 'Brasil' que ainda não é ou nunca foi de todo -, a linguagem assume um inesperado papel decisivo. Em outras palavras pois é delas de que se trata -, como o objeto não provê uma referência estável, cabe à linguagem recobrir sua insuficiência com um número sem-fim de interpretações daquilo que deveria fazer do brasil, Brasil. (ROCHA, 2003, p. 23).

Entretanto, o Brasil que se apresenta como uma possível solução de futuro tem na multiplicidade estruturada em indefinição um impedimento para que haja qualquer espécie de definição, agora ou depois. O paradoxo se desloca para outro, complexo e insolúvel, onde o

\section{POLÊM!CA $\mid$ LABORE}


que nos (in)define não possibilita perspectivas de futuro. A ficção ganha a realidade com uma espécie de prisão permanente no presente.

Esta "definição indefinida" dos brasileiros sobre si mesmos gerou uma constituição dos limites de identidade em bordas moles. Nos diferentes encontros entre indivíduos e grupos, as indefinições caracterizam um limite "mole" que não se funde, mas negocia. Ou seja, as bordas moles passam a ser a identidade da não identidade. Isto gera, no encontro entre indivíduos e grupos, um processo de negociação dos próprios limites que vão se adaptando quando se aproximam. Não há fusão, nem sincretismo, mas negociação nos limites.

As identidades se mantém, mesmo que maleáveis e sujeitas a alterações em suas bordas, e o que as definem é o encontro com outros indivíduos e grupos. Os brasileiros, por conta desta forma de se representarem, negociam o tempo todo. Negociam no cotidiano nas tarefas mais comuns, negociam no mundo do trabalho, negociam nas práticas religiosas e negociam na vida social e política.

As regras claras e bem definidas não existem. Poucas situações sociais de regras claras são cumpridas. E é nesta perspectiva que a corrupção é pensada socialmente pelos brasileiros. A contradição lógica no pensamento dos brasileiros sobre corrupção, onde todos são corruptos e ao mesmo tempo a corrupção é restrita aos agentes públicos, está referida ao processo de não atribuição de valência que impede a definição do que vem a ser corrupção para os brasileiros. Assim sendo, a corrupção tem sua atribuição de sentido e significado negociado nas circunstâncias e um evento assemelhado pode, ou não, ter a mesma interpretação de valor. Em geral, não há tolerância, a não ser com os ofícios sujos, mas uma indefinição conceitual.

Desta maneira, no cotidiano, quando em situações da vida comum o benefício é distribuído pelos protagonistas, isto não é, por seu efeito, considerado corrupção, não porque há justificativas constituídas para tal ato, mas porque não é pensado como tal.

A corrupção é um problema para os brasileiros em duas situações: quando pensam que atos cometidos por agentes públicos passaram dos "limites", mesmo que estes sejam fluídos e instáveis, por afetarem de modo direto a vida dos cidadãos, em geral, vinculados à condição econômica do Brasil; e outro, quando há perspectivas ou expectativas de mobilidade social, e aí é preciso desconstruir políticas, acontecimentos, ou indivíduos que as promoveram, e a associação com a corrupção é um dos elementos centrais no processo.

\section{POLÊM!CA $\mid$ LABORE}


Os brasileiros pensam a si mesmos como corruptos e ao mesmo tempo como não corruptos. Uma das razões fundamentais para que pensem assim é que a corrupção não é um valor, nem tem atribuição clara de sentidos e significados, o que a transforma em um ato das negociações permanentes entre os brasileiros em suas bordas moles.

\section{Referências}

AVRITZER, L.; BIGNOTTO, N.; GUIMARÃES, J.; STARLING, H. M. M. (orgs.) Corrupção: ensaios e críticas. Belo Horizonte: Editora UFMG, 2008.

CASTRO, R. V. O quarto de Getúlio: representações e memória na política brasileira. In: SÁ, C. P. (org.).

Memória, imaginário e representações sociais. Rio de Janeiro: Museu da República, 2005. (p. 199-208).

DIEGUES, C. (1976). Xica da Silva. [Filme-vídeo]. C. Diegues, Dir. Brasil: J.B. Produções Cinematográficas Ltda. $35 \mathrm{~mm}, 114 \mathrm{~min}$, color. son.

FARR, R. M. As raízes da psicologia social moderna. Brasil: Vozes, 2013.

FURTADO, G. F. Chica da Silva e o contratador de diamantes: o outro lado do mito. São Paulo: Companhia das Letras, 2003.

IBGE - Instituto Brasileiro de Geografia e Estatística. Estatísticas do século XX. Disponível em: <http://seculoxx.ibge.gov.br/>. Acesso em: 07 ago. 2016.

JODELET, D. Representações sociais: um domínio em expansão. In: sociais. Rio de Janeiro: EdUERJ, 2001. (org.). As representações

LARA, S. H. Fragmentos setecentistas: escravidão, cultura e poder na América portuguesa. São Paulo: Companhia das Letras, 2007.

MATOS, G. Gregório de Matos. Obra Poética. vol.1. Rio de Janeiro: Record, 1990.

MOSCOVICI, S. A psicanálise, sua imagem e seu público. Petrópolis: Vozes, 2012.

Representações sociais: investigações em psicologia social. Petrópolis: Vozes, 2003.

MOURA, C. Dicionário da escravidão negra no Brasil. São Paulo: Edusp, 2004.

NEITZEL, S.; WELZER, H. Soldados, sobre lutar, matar e morrer: as práticas bárbaras dos soldados do $3^{\circ}$ reich. São Paulo: Companhia das Letras, 2014.

NOVAES, C. E. O chá das duas: dna corrupção e dna subversão. Rio de Janeiro: Editora Nórdica, 1978.

NPHED - Núcleo de Pesquisa em História Econômica e Demográfica. Publicação crítica do recenseamento geral do império do brasil de 1872. 2012. Disponível em: 〈http://www.nphed.cedeplar.ufmg.br/pop72/>. Acesso em: 07 ago. 2016.

POSSENTI, S. Humor, língua e discurso. São Paulo: Contexto, 2014.

RIOS, A. L.; MATTOS, H. Memórias do cativeiro: família, trabalho e cidadania no pós-abolição. Rio de Janeiro: Civilização Brasileira, 2005.

\section{POLÊM!CA $\mid$ LABORE}

Polêmica - Revista Eletrônica da Uerj - Rua São Francisco Xavier, 524, $1^{\circ}$ andar

bloco D, sl.1001 • Tels.: +55 21 2334-4088/4087 • http://www.e-publicacoes.uerj.br/index.php/polemica/index

http://www.labore.uerj.br • laboreuerj@yahoo.com.br 
ROCHA, J.C.C. Introdução. In: (org.). Nenhum Brasil existe - Pequena enciclopédia. Rio de Janeiro: Topbooks Editora, 2003.

RODRIGUES, N. Os Africanos no Brasil. Brasília: Ed. UNB, 2004.

ROMERO, S. História da literatura brasileira, Tomo 1. Rio de Janeiro: Imago, 2001.

SANTOS, I. C. L. “A cor já não ajuda, você vai direito!”. Um estudo de representações sociais acerca dos efeitos da mobilidade social da mulher negra na contemporaneidade. Tese Não-Publicada (Doutorado em Psicologia Social) - Programa de Pós-Graduação em Psicologia Social, Universidade do Estado do Rio de Janeiro, Rio de Janeiro, 2016.

SOARES, L.C. O "Povo de Cam" na Capital do Brasil: a escravidão urbana no Rio de Janeiro do Sec. XIX. Rio de Janeiro: Faperj - 7 letras, 2007.

VAZ, C. A memória social da escravidão urbana no Rio de Janeiro. Tese Não-Publicada (Doutorado em Psicologia Social), Programa de Pós-Graduação em Psicologia Social, Universidade do Estado do Rio de Janeiro, Rio de Janeiro, 2016.

Recebido em: 15/12/2016.

Aceito em: 31/03/2016.

\section{POLÊM!CA $\mid$ LABORE}

